\title{
EXPRESSION OF CANCER-ASSOCIATED GENES IN PROSTATE TUMORS
}

\author{
E.E. Rosenberg ${ }^{1, *}$ **, G.V. Gerashchenko ${ }^{1, *}$, N.V. Hryshchenko ${ }^{1}$, L.V. Mevs ${ }^{1}$, K.A. Nekrasov ${ }^{1}$, \\ R.A. Lytvynenko' ${ }^{2}$ Y.V. Vitruk ${ }^{2}$, O.P. Gryzodub ${ }^{3}$, E.A. Stakhovsky ${ }^{2}$, V.I. Kashuba ${ }^{1}$ \\ ${ }^{1}$ Institute of Molecular Biology and Genetics NAS of Ukraine, Kyiv 03680, Ukraine \\ ${ }^{2}$ National Cancer Institute, Kyiv 03022, Ukraine \\ ${ }^{3}$ Institute of Urology, National Academy of Medical Sciences of Ukraine, Kyiv 04053, Ukraine
}

\begin{abstract}
Background: Prostate cancer is one of the most common male cancers in Western countries and takes the third place in morbidity in Ukraine. It is a highly heterogeneous disease. Aim: To analyze relative expression levels of the TGFB1, ILIB, FOS, EFNA5, TAGLN, $P L A U$, and EPDR1 genes in malignant and non-malignant prostate tissues. Materials and Methods: Total RNA was isolated from 16 prostate adenomas, 37 prostate adenocarcinomas, and 29 conventionally normal prostate tissues. To analyze relative gene expression levels the quantitative real-time polymerase chain reaction was performed. Results: The significant alterations in the relative expression levels were found in all analyzed sample groups for 4 genes: FOS, EFNA5, IL1B, and TGFB1. We have found that FOS and EFNA5 were more frequently overexpressed in carcinomas with Gleason score $\leqslant 7$, compared with adenomas. On contrary, PLAU expression levels were decreased more frequently in prostate cancers, compared with conventionally normal tissues. Noteworthy, we found positive correlation between $I L 1 B$ expression level and PSA (for patients with slight PSA increase, no more than $20.0 \mathrm{ng} / \mathrm{ml}$ ). Conclusion: The EFNA5, FOS, IL1B, PLAU, and TGFB1 genes that showed significant expression alterations in prostate tumors, compared with conventionally normal prostate tissue, may play role in prostate cancer development and should be further investigated. Key Words: prostate cancer, prostate adenomas, relative gene expression.
\end{abstract}

Prostate cancer is the most frequently diagnosed male cancers in Western countries, taking the third place in morbidity and the second place in mortality in Ukraine in the year 2014 [1, 2]. Despite numerous studies that aimed to shed light on the molecular mechanisms, underlying initiation and subsequent progression of prostate tumors, the precise mechanism and factors stimulating the fast transition to metastatic cancer are not yet fully understood. One of the key factors of these pitfalls is a high level of heterogeneity of this malignancy. Prostate cancer is characterized by not only interpatient heterogeneity [3], but more than a half of malignant prostate tumor of one patient contains several disease focuses $[4,5]$. These biological differences result in the differential prostate cancer-specific mortality rates [6] and make selection of the appropriate therapy for patients the real challenge [7].

Earlier, we have analyzed the gene expression pattern in the prostate cancer cell lines, using a quantitative real-time polymerase chain reaction (qPCR) microarrays, in order to find differentially expressed genes and deduce the possible signaling pathways, involved in transformation into androgen-independent type. The studied prostate cancer cell lines LNCaP, DU145, and PC3 showed different invasion and metastatic potential; LNCaP cells are androgen-dependent, while PC3 - androgen-independent $[8,9]$. Based on results of these experiments, the following genes, namely TAGLN, EFNA5, IL1B, PLAU, $T G F B 1, E P D R 1$, and FOS were selected to study the clinical samples. These genes are involved in different cellular

Submitted: January 25, 2017.

*These authors contributed equally to this work

${ }^{* *}$ Correspondence: E-mail: y.e.rozenberg@imbg.org.ua Abbreviations used: CNT - conventionally normal tissues; GI Gleason score; PSA - prostate-specific antigen; qPCR - quantitative real-time PCR; RE - relative expression. pathways, EFNA5, TAGLN, and EPDR1, for example, play a role in cell-cell and cell-matrix adhesion, that are diminished during tumor progression [10]. Additionally, TAGLN is involved in the p53 pathway [11] and IL1B - in the NF-KB pathway [12]. It was shown that PLAU participates in the control on invasion and metastasis [13]. It was reported also, that TGFB1 could promote angiogenesis and the epithelial to mesenchymal cell transition [14]. The transcriptional factor FOS is involved in different cellular processes, including inflammation [15].

In the present study we aimed to validate the previously obtained data and to analyze relative expression (RE) levels of the TGFB1, IL1B, FOS, EFNA5, TAGLN, PLAU, and EPDR1 genes in malignant and non-malignant prostate tissues.

\section{MATERIALS AND METHODS}

Tissue samples. Prostate adenoma and carcinoma tissue specimens from peripheral zone, as well as conventionally normal tissues (CNT) from opposite transitional zone of prostate were collected after surgical resection of prostate tumors from patients at the Institute of Urology of National Academy of Medical Sciences of Ukraine and National Cancer Institute (Kyiv, Ukraine) and were immediately frozen in liquid nitrogen. In total, 16 samples of benign prostatic hyperplasia (adenoma) and 37 adenocarcinoma samples were collected; among them 29 samples were supplemented with the paired CNT (Table 1). Among adenocarcinoma samples there were 23 samples of Gleason score $(\mathrm{Gl}) \leqslant 7$ and 14 samples of $\mathrm{Gl}>7$. Twenty-nine samples represented the stages I and II; eight samples were of the stages III and IV. The samples were collected in accordance with the Declaration of Helsinki and approved by the guidelines issued by the Ethic Committee of the Institute of Urology and National Cancer Institute, Kyiv, Ukraine. Also, all patients gave written informed consent. 
Table 1. Clinical and pathological characteristics of prostate samples and the total prostate-specific antigen (PSA) levels in blood serum of patients

\begin{tabular}{|c|c|c|c|c|c|c|c|c|c|}
\hline \multicolumn{5}{|c|}{ Paired carcinoma samples } & \multicolumn{5}{|c|}{ Paired carcinoma samples } \\
\hline № & TNM & Stage & Gl & $\begin{array}{l}\text { PSA, } \\
\mathrm{ng} / \mathrm{ml}\end{array}$ & № & TNM & Stage & Gl & $\begin{array}{l}\mathrm{PSA}, \\
\mathrm{ng} / \mathrm{ml}\end{array}$ \\
\hline 1 & T1cNxM0 & I & 7 & 8.19 & 20 & T2cNxM0 & II & $>7$ & 90.00 \\
\hline 2 & T2aNxM0 & II & 7 & 9.30 & 21 & T2cNxM0 & II & $<7$ & 25.20 \\
\hline 3 & T2aNxM0 & II & $>7$ & 7.13 & 22 & T2cNxM0 & II & $>7$ & 13.30 \\
\hline 4 & T2aNxM0 & II & 7 & 18.60 & 23 & T2cNxM0 & II & $>7$ & 84.20 \\
\hline 5 & T2aNxM0 & II & 7 & 11.70 & 24 & T3bNxM0 & III & $>7$ & 106.00 \\
\hline 6 & T2aNxM0 & II & 7 & 5.60 & 25 & T3bNxM0 & III & $>7$ & 51.00 \\
\hline 7 & T2aNOMO & II & $>7$ & 37.80 & 26 & T3bNxM0 & III & 7 & 53.00 \\
\hline 8 & $\mathrm{~T} 2 \mathrm{bNxM0}$ & II & 7 & 13.90 & 27 & T3bNxM0 & III & $<7$ & 23.57 \\
\hline 9 & T2bNxM0 & ॥ & $<7$ & 6.50 & 28 & T3bNxM0 & III & $>7$ & 20.90 \\
\hline 10 & T2bNxM0 & II & $>7$ & 33.00 & 29 & T2cN0M1 & IV & $>7$ & 22.60 \\
\hline 11 & T2bNxM0 & II & 7 & 6.92 & \multicolumn{5}{|c|}{ Unpaired carcinoma samples } \\
\hline 12 & T2bNOMO & $\|$ & 7 & 5.03 & 1 & T1cN0Mx & II & $<7$ & 9.40 \\
\hline 13 & $\mathrm{~T} 2 \mathrm{cNxM0}$ & II & $>7$ & 20.29 & 2 & $\mathrm{~T} 2 \mathrm{~N}$ & II & $<7$ & 8.34 \\
\hline 14 & $\mathrm{~T} 2 \mathrm{cNxM0}$ & II & 7 & 19.27 & 3 & T2NOMO & II & $<7$ & 25.24 \\
\hline 15 & T2cNxM0 & II & $>7$ & 25.08 & 4 & T2NOMO & II & $<7$ & 3.80 \\
\hline 16 & $\mathrm{~T} 2 \mathrm{cN}$ & II & 7 & 19.8 & 5 & $\mathrm{~T} 2 \mathrm{bN}$ & II & 7 & 11.45 \\
\hline 17 & $\mathrm{~T} 2 \mathrm{cNxM0}$ & II & $<7$ & 27.30 & 6 & T2cNOMO & II & 7 & 17.00 \\
\hline 18 & $\mathrm{~T} 2 \mathrm{cNxM} 0$ & II & $<7$ & 29.08 & 7 & T3NxMx & III & $>7$ & - \\
\hline 19 & T2cNxM0 & II & $>7$ & 17.00 & 8 & T3aNxM0 & III & 7 & - \\
\hline
\end{tabular}

Isolation of the total RNA. Total RNA samples from the frozen tissues were isolated, using TRI Reagent (Sigma-Aldrich, USA), according to the manufacturer's instructions. The quality of the total RNA was assessed, using electrophoresis; purity was analyzed, using the NanoDrop 2000 spectrophotometer (Thermo Fisher Scientific, USA). RNA was stored then at $-80^{\circ} \mathrm{C}$.

Synthesis of the first strand cDNA. The isolated total RNA was treated with DNAse I (Thermo Scientific, USA). cDNA was synthesized from $2 \mu \mathrm{g}$ of total RNA, using the RevertAid H Minus First Strand cDNA Synthesis kit (Thermo Scientific, USA). All procedures were performed, according to the manufacturer's instructions.

Quantitative real-time PCR. qPCR was performed, using the Maxima SYBR Green/ROX qPCR Master Mix (Thermo Scientific, USA) and CFX96 Touch Real-time PCR Detection System (Bio-Rad, USA), according to the manufacturer's instructions. The following conditions were used: initial denaturation at $95^{\circ} \mathrm{C}$ for $10 \mathrm{~m}$, followed by 40 cycles of denaturation at $95^{\circ} \mathrm{C}$ for $15 \mathrm{~s}$, annealing at $60{ }^{\circ} \mathrm{C}$ for $30 \mathrm{~s}$, and extension at $72{ }^{\circ} \mathrm{C}$ for 30 s. Primers used in qPCR are shown in Table 2. All data were analyzed, using qRT-PCR Data Analysis Software (Bio-Rad, USA). This integrated web-based software package automatically calculates $2^{-\Delta \Delta C t}$-based relative quantities from the uploaded raw threshold cycle data. The TBP gene was used as a reference gene [16]. The inter-run calibration was used to correct run-to-run differences. As calibrator, a mixture of two cDNA from adenoma samples was used. The Livak method $2^{-\Delta \Delta C t}$ of calculation of gene RE was used. Specific amplification was confirmed, using the melting curve method.

Statistical analysis. The Kolmogorov - Smirnov and Lilliefors tests were used for assessing normal- ity of distribution for levels of RE. Contingency tables were used for assessment of association of RE levels in groups of adenomas, CNT, and carcinomas with the $\mathrm{Gl}$ and levels of the PSA. The permutation based Fisher's exact test was used for estimation of significance. The Wilcoxon test was used to analyze differences in RE levels between carcinomas and matched CNT. Logistic regression was used to analyze associations between RE levels and clinical data of patients. $p$-values $<0.05$ were considered as the statistically significant [17]. All statistical procedures were performed, using the STATISTICA 10.0 software (StatSoft, USA) and also the Open Source Epidemiologic Statistics for Public Health (available at http://www.openepi.com/). Also the software ORIGIN 8.5 (OriginLab, USA) was used.

\section{RESULTS}

Levels of RE of the EFNA5, EPDR1, FOS, IL1B, PLAU, TAGLN, TGFB1 genes in comparison with TBP were assessed in all the samples (Fig. 1). In group of patients with adenomas a median age was 66.5 years, in the range 60-77 years. In group of patients with adenocarcinomas median age was 63 years, in the range $48-80$ years. For RE values descriptive statistics was performed (Fig. 2). We observed abnormal distributions in RE for all genes, except FOS, TAGLN, and EPDR1 in carcinomas and for IL1B in CNT, according to Kolmogorov - Smirnov and Lilliefors analysis. Moreover, we found that mean and median values of RE of TAGLN, EFNA5, and EPDR1 genes in adenomas were quite similar. Noteworthy, RE of all the genes showed the high level of dispersion in adenomas, carcinomas, and CNT: for example, range of FOS RE in CNT was 3.028-285.813. Besides that, standard deviation values of the RE of the all genes in CNT, carcinoma and adenoma groups were quite high. For example, $\mathrm{RE}$ of the FOS gene was even higher than values of medians: $\mathrm{ME}=3.383$ in carcinomas, while $\mathrm{SD}=11.693$.

To analyze the possible association of RE levels in different prostate tumors with contingency tables, $\mathrm{RE}$ levels and clinical data were divided into nominal meanings. Thus, RE levels were divided into 3 nominal meanings: $1^{\text {st }}$ - without alterations (RE levels were in the range $0.41-2.09), 2^{\text {nd }}-$ with decreased $R E$ $(R E \leqslant 0.4)$ and $3^{\text {rd }}-$ with increased $R E(R E \geqslant 2.1)$. Contingency table was created, where in the rows there are nominal meanings of RE and in the columns there are nominal meanings of groups (Table 3).

It is well accepted that $\mathrm{Gl}$ is used for the classification of prostate cancers. As described in the European Association of Urology guidelines, patients with localized or locally advanced prostate cancer with GI higher than 7 are in the group of a high-risk of recurrence [18]. Because of that,

Table 2. Sequences of $q P C R$ primers

\begin{tabular}{|c|c|c|c|c|}
\hline Gene name & Accession number & Forward primer & Reverse primer & Amplicon length, bp \\
\hline EFNA5 & NM_001962 & 5'-CTGGATGTGTGTGTTCAGCC-3' & 5'-ATGGTAGTCACCCCTCTGGA-3' & 106 \\
\hline EPDR 1 & NM_017549 & 5'-CTGCTTTCAGGACACTCATC-3' & 5' -GCTGGCATTCTTCACTCTAC-3' & 146 \\
\hline FOS & NM_005252 & 5'-CTACCACTCACCCGCAGACT-3' & 5'-GTGGGAATGAAGTTGGCACT-3' & 102 \\
\hline$I L 1 B$ & NM_000576 & 5'-GAAGCTGATGGCCCTAAACA-3' & 5'-AAGCCCTTGCTGTAGTGGTG-3' & 110 \\
\hline PLAU & NM_002658 & 5'-CACACACTGCTTCATTGATTAC-3' & $5^{\prime}$-ССАССТCAAACTTCATCTCC-3' & 104 \\
\hline TAGLN & NM_001001522 & 5'-AAGAATGATGGGCACTACCG-3' & 5'-ACTGATGATCTGCCGAGGTC-3' & 186 \\
\hline TGFB1 & NM_ 000660 & 5'-CCCTGGACACCAACTATTGC-3' & 5'-CTTCCAGCCGAGGTCCTT-3' & 92 \\
\hline$T B P$ & $\mathrm{NM}^{-0} 003194$ & 5'-TGCACAGGAGCCAAGAGTGAA-3' & $5^{\prime}$-CACATCACAGCTCCCCACCA-3' & 132 \\
\hline
\end{tabular}


TAGLN

(a)

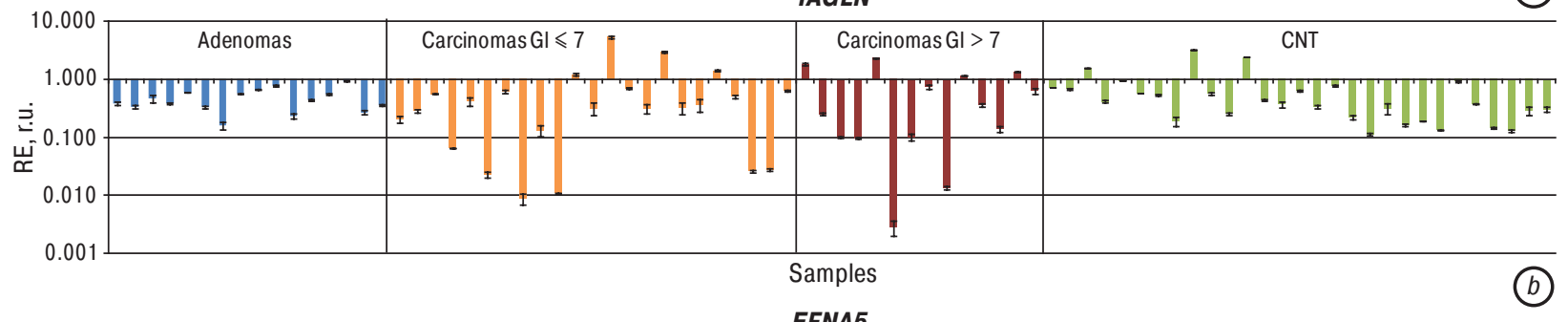

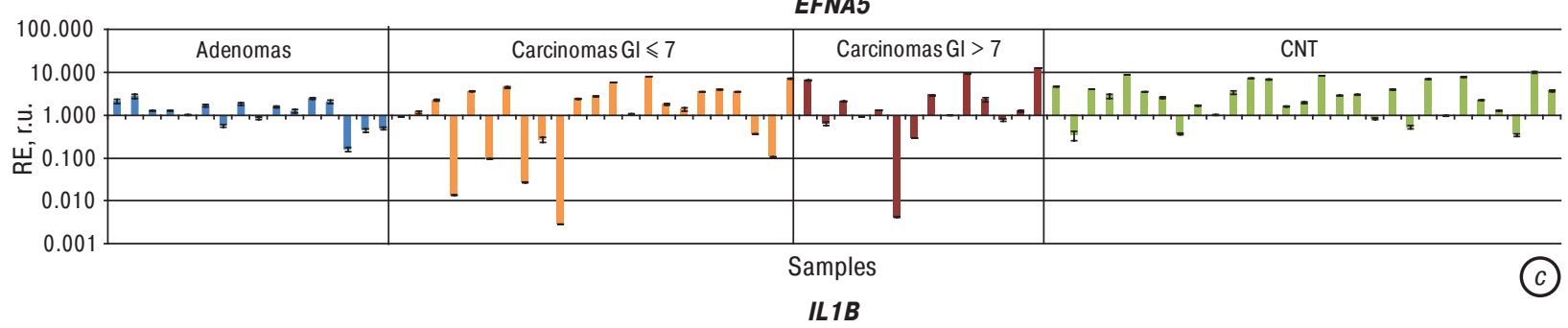

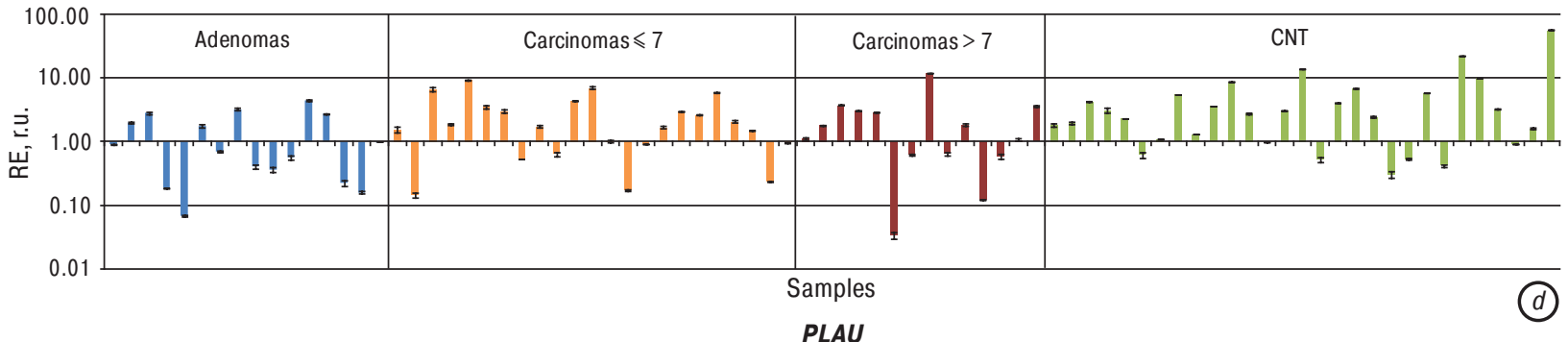

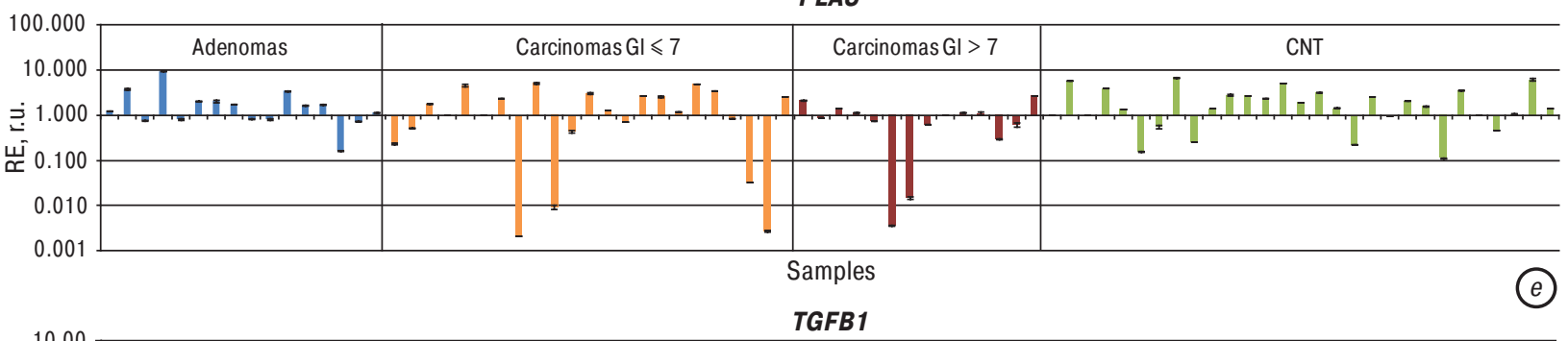

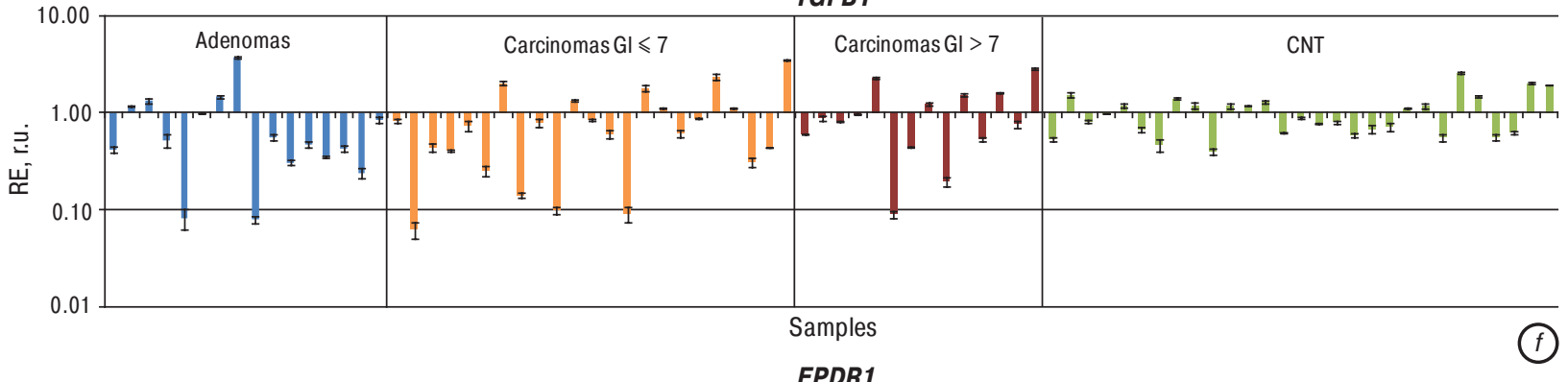

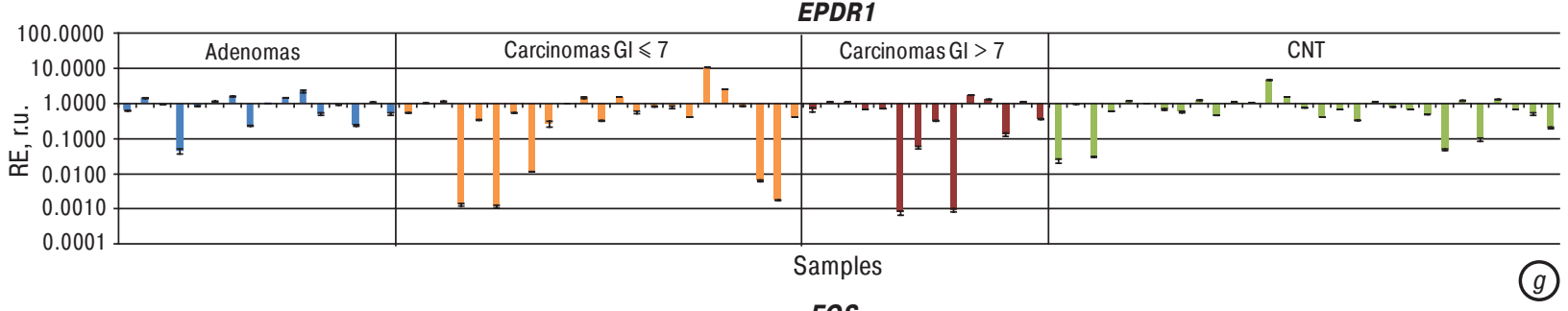

FOS

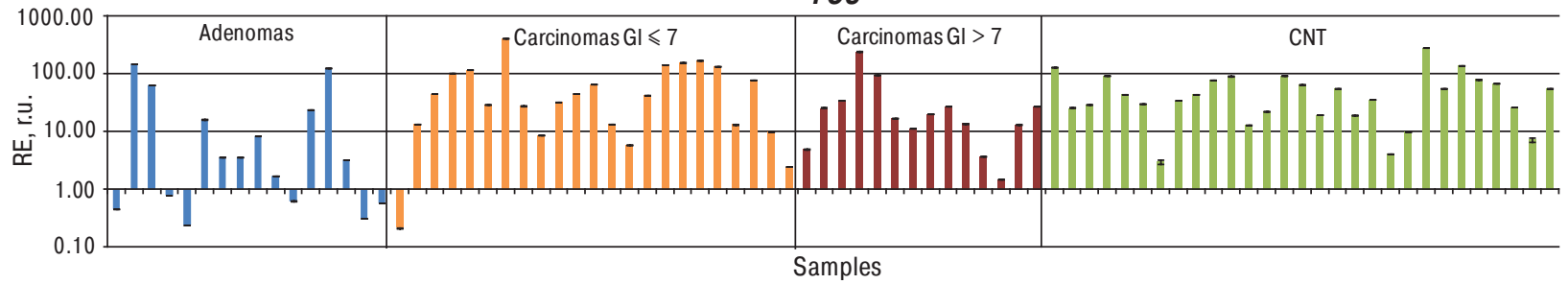

Fig. 1. RE in adenomas (light blue color), carcinomas (red color), and CNT (green color) for genes: a) TAGLN, b) EFNA5, $c$ ) IL1B, d) PLAU, e) TGFB1, f) EPDR1, and g) FOS 
Table 3. The contingency tables of RE levels in adenomas', carcinomas' and CNTs' groups. Significance was calculated, using the permutation based Fisher's exact test

\begin{tabular}{|c|c|c|c|c|}
\hline \multirow{3}{*}{ Gene } & \multirow{3}{*}{ RE levels } & \multicolumn{3}{|c|}{ Number of samples with relevant RE changes } \\
\hline & & \multicolumn{3}{|c|}{ Group } \\
\hline & & Adenoma $(n=16)$ & Carcinoma $(\mathrm{n}=37)$ & $\operatorname{CNT}(n=29)$ \\
\hline \multirow[t]{3}{*}{ TGFB1 } & I & 9 & 24 & 27 \\
\hline & \| & $6^{2}$ & $9^{3}$ & $1^{2,3}$ \\
\hline & III & 1 & $4^{3}$ & $1^{3}$ \\
\hline \multirow[t]{3}{*}{$I L 1 B$} & I & 6 & 18 & 11 \\
\hline & II & $6^{2}$ & 5 & $1^{2}$ \\
\hline & III & $4^{2}$ & 14 & $17^{2}$ \\
\hline \multirow[t]{3}{*}{ FOS } & I & 5 & 1 & 0 \\
\hline & II & 2 & 1 & 0 \\
\hline & III & $\mathbf{9}^{1,2}$ & $35^{1}$ & $29^{2}$ \\
\hline \multirow[t]{3}{*}{ EFNA5 } & I & 12 & 10 & 8 \\
\hline & II & $\mathbf{1}^{1}$ & $10^{1}$ & 3 \\
\hline & III & $3^{1,2}$ & $17^{1}$ & $18^{2}$ \\
\hline \multirow[t]{3}{*}{ TAGLN } & I & 9 & 13 & 12 \\
\hline & II & 7 & 21 & 15 \\
\hline & III & 0 & 3 & 2 \\
\hline \multirow[t]{3}{*}{ PLAU } & I & 12 & 17 & 13 \\
\hline & II & 1 & 9 & 5 \\
\hline & III & 3 & 11 & 11 \\
\hline \multirow[t]{3}{*}{ EPDR 1} & I & 12 & 21 & 22 \\
\hline & II & 3 & 14 & 6 \\
\hline & III & 1 & 2 & 1 \\
\hline
\end{tabular}

Note: RE levels: I $-0.41-2.09, \mathrm{II}-\leqslant 0.4, \mathrm{III}-\geqslant 2.1 ;{ }^{1}-$ significant changes between adenomas and carcinomas; ${ }^{2}$ - significant changes between adenomas and CNT; ${ }^{3}$ - significant changes between carcinomas and CNT. In bold numbers marked sample frequencies with significant changes in groups.

we created the contingency table, where in the rows there are the nominal meanings of RE and in the columns there are nominal meanings of carcinoma samples with $\mathrm{GI} \leqslant 7(\mathrm{n}=23)$ and $>7(\mathrm{n}=14)$ (Table 4). We analyzed the $\mathrm{RE}$ in the paired carcinoma samples, compared with CNT in order to find associations in groups with different nominal meanings of Gl. Therefore, we used the contingency table, where in the rows there are the nominal meanings of RE and in the columns there are the nominal meanings of carcinoma samples with $\mathrm{Gl} \leqslant 7(n=14)$ and $>7(n=15)$. The contingency table was generated in order to analyze associations in RE levels in the group of carcinomas compared with CNT and levels of the PSA. In the rows there

Table 4. The contingency tables of RE levels in adenomas' group and carcinomas' groups with different GI. Significance was calculated, using the permutation based Fisher's exact test

\begin{tabular}{|c|c|c|c|c|}
\hline \multirow{3}{*}{ Gene } & \multirow{3}{*}{ RE levels } & \multicolumn{3}{|c|}{ Number of samples with relevant RE changes } \\
\hline & & \multicolumn{3}{|c|}{ Group } \\
\hline & & Adenoma $(n=16)$ & $\begin{array}{c}\text { Carcinoma Gl } \leqslant 7 \\
(n=23)\end{array}$ & $\begin{array}{c}\text { Carcinoma Gl }>7 \\
(n=14)\end{array}$ \\
\hline \multirow[t]{3}{*}{ TGFB1 } & I & 9 & 14 & 10 \\
\hline & II & 6 & 7 & 2 \\
\hline & III & 1 & 2 & 2 \\
\hline \multirow[t]{3}{*}{$I L 1 B$} & I & 6 & 11 & 7 \\
\hline & ॥ & 6 & 3 & 2 \\
\hline & III & 4 & 9 & 5 \\
\hline \multirow[t]{3}{*}{ FOS } & I & 5 & 0 & 1 \\
\hline & II & 2 & 1 & 0 \\
\hline & III & $9^{1}$ & $22^{1}$ & 13 \\
\hline \multirow[t]{3}{*}{ EFNA5 } & 1 & 12 & 4 & 6 \\
\hline & II & $1^{1}$ & $8^{1}$ & 2 \\
\hline & III & $3^{1}$ & $11^{1}$ & 6 \\
\hline \multirow[t]{3}{*}{ TAGLN } & I & 9 & 8 & 5 \\
\hline & II & 7 & 13 & 8 \\
\hline & III & 0 & 2 & 1 \\
\hline \multirow[t]{3}{*}{ PLAU } & I & 12 & 9 & 8 \\
\hline & II & 1 & 5 & 4 \\
\hline & III & 3 & 9 & 2 \\
\hline \multirow[t]{3}{*}{ EPDR 1} & I & 12 & 13 & 8 \\
\hline & II & 3 & 8 & 6 \\
\hline & III & 1 & 2 & 0 \\
\hline
\end{tabular}

Note: RE levels: I $-0.41-2.09, \mathrm{II}-\leqslant 0.4, \mathrm{III}-\geqslant 2.1 ;{ }^{1}-$ significant changes between adenoma and carcinoma samples with $\mathrm{Gl} \leqslant 7$. In bold numbers marked sample frequencies with significant changes in groups. are the meanings of RE and in the columns there are the nominal meanings of the PSA levels: $1^{\text {st }}$ - with lowincrease of PSA level ( $n=15$, range 5.03-20.29) and $2^{\text {nd }}$ - with high increase of PSA level ( $n=14$, range 20.9-106.0). We do not show these tables, because no significant alterations in analyzed groups were found.

Based on the analysis of the data presented in Table 3, we found 4 genes: FOS $(p=0.0001), \operatorname{EFNA5}(p=0.0030)$, IL1B $(p=0.0180)$, and TGFB1 $(p=0.0300)$ that show statistically significant alterations in frequencies of samples with altered RE between adenomas, carcinomas, and CNT. The significant changes were observed between adenomas and carcinomas in RE of FOS $(p=0.0026)$ and EFNA5 ( $p=0.0047)$. Moreover, we found REalterations between carcinomas and CNT for TGFB1 gene $(p=0.0233)$. Also we found alterations when comparing adenomas and CNT in RE of the FOS $(p=0.0005), I L 1 B(p=0.0061)$, TGFB1 $(p=0.0082)$, and EFNA5 ( $p=0.0084)$ genes. Noteworthy, after the analysis of the Table 4 data, no differences in frequencies of samples with altered RE in nominal meanings with different Gl was found. However, the FOS ( $p$ $=0.0134)$ and EFNA5 $(p=0.0077)$ genes showed altered REbetween carcinomas and adenomas. Particularly, there were differences between adenomas and carcinomas with the $\mathrm{Gl} \leqslant 7$ (FOS $p=0.0073$, EFNA5 $p=0.0014)$.

It is well known, as we mentioned already, that prostate cancer is highly heterogeneous genetically and also, tumor even in patient could be multifocal [19]. The molecular nature of such heterogeneity is still not characterized. Therefore, it is important to show any differences between tumor and CNT derived from the same prostate. As one of factors that may vary, we have chosen the gene RE levels. We compared the RE values in the paired carcinoma - CNT samples, using theWilcoxon test, and found the differential RE of the PLAU $(p=0.0388)$ gene. Consequently, we calculated the $\mathrm{RE}$ fold change in the paired carcinoma - CNT samples. The fold change two or more times was considered as significant [20]. We found that RE was decreased in $27.6 \%$ of carcinomas compared with CNT, while RE was increased in $6.9 \%$ of samples for TGFB $1 ; 27.6 \%$ and $17.3 \%$, respectively, — for IL1B; $13.8 \%$ and $24.1 \%$ - for FOS; $37.9 \%$ and $6.9 \%$ - for EFNA5; $34.5 \%$ and $24.1 \%$ - for TAGLN; $31.0 \%$ and $10.3 \%$ - for $P L A U$, and $31.0 \%$ and $13.8 \%$ - for EPDR1.

We did not find any statistically significant associations, using the permutation Fisher's exact test in the RE levels between carcinomas and CNT and GI, nor did we found for RE and levels of the PSA. Moreover, we did not find correlations between mentioned above groups, using the Spearman test. However, we found moderate direct correlations between all genes, except FOS (0.42-0.60). In patients with the slight increase of the PSA levels (no more than $20.0 \mathrm{ng} / \mathrm{ml}$ ) we found the positive correlation between RE of IL 1B gene and PSA level (nonparametric regression analysis: $\mathrm{OR}=2.1 ; p=0.0377$ ).

\section{DISCUSSION}

We observed a high level of dispersion of the REvalues for all the genes in all analyzed groups. It could be due to genetic heterogeneity that takes place not only in pros- 

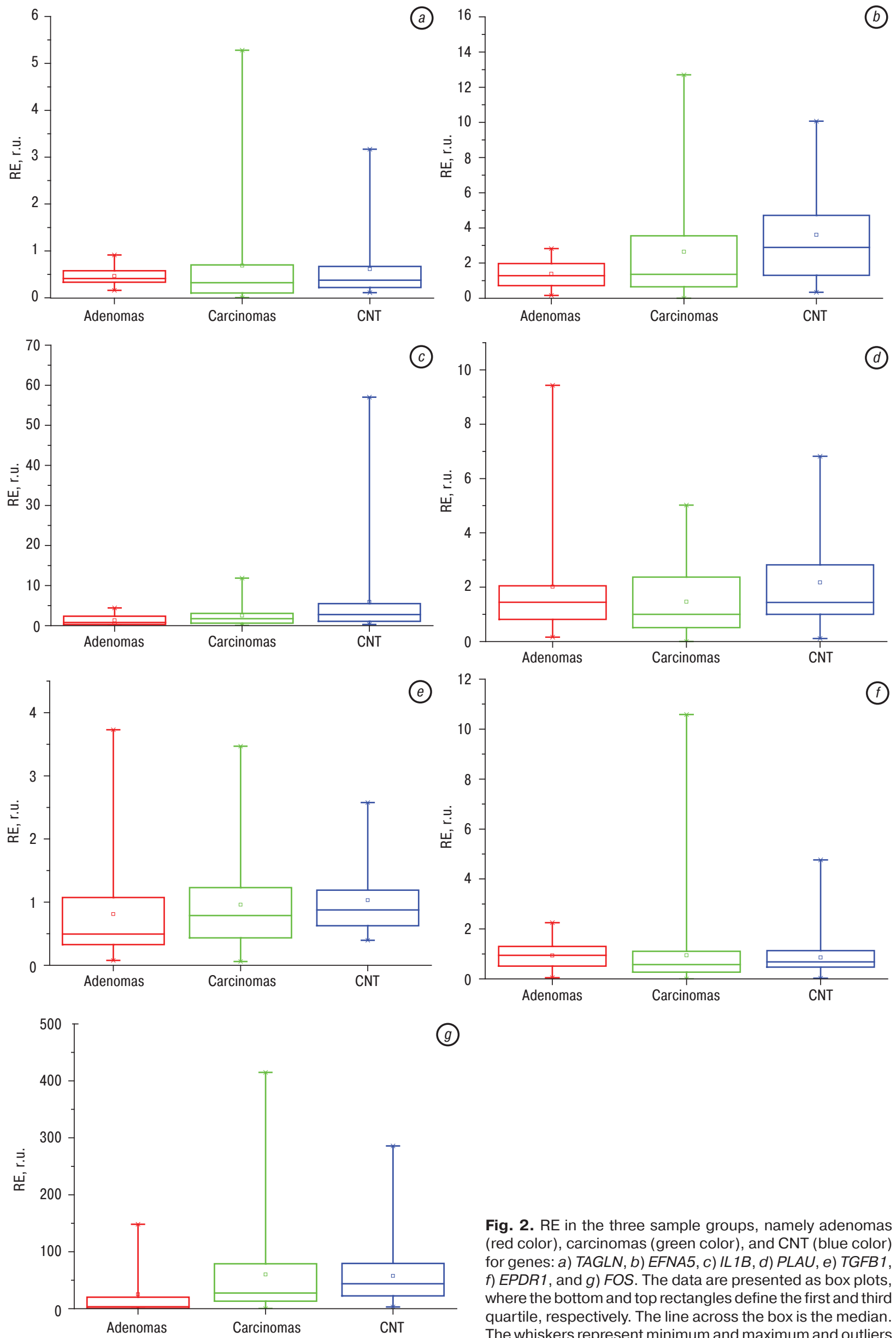

Fig. 2. RE in the three sample groups, namely adenomas (red color), carcinomas (green color), and CNT (blue color) for genes: a) TAGLN, b) EFNA5, c) IL1B, d) PLAU, e) TGFB1, f) EPDR1, and g) FOS. The data are presented as box plots, where the bottom and top rectangles define the first and third quartile, respectively. The line across the box is the median. The whiskers represent minimum and maximum and outliers are depicted by asterisks 
tate cancers, butalso in adenomas and CNT. Probably, the investigated genes are differently regulated at the different conditions, which may depend on individual hormonal state. Also, this might be due to a complex mixture of cell pulls that differ not only by the origin (stromal and epithelial), butalso by various stages of progression in individual samples [21]. Thus, the histological tissue analysis prior experimental part assessing gene expression, is crucial and very important. As was discussed above, we found significant differences of RE levels for a set of genes, namely FOS, EFNA5, IL1B, and TGFB1, when compared samples of adenomas, carcinomas, and CNT.

$\mathrm{RE}$ of $F O S$ was increased frequently in carcinomas (35 out of 37), compared with adenomas (9 out of 16) and in all CNT, compared with adenomas (9 out of 16). This might suggest that the FOS proto-oncogene is activated in carcinomas. It is known that Fos is a subunit of the AP-1 transcription factor [22]. Overexpression of FOS was found in ovary tumors [23] and osteosarcomas [24]. This was associated with an advanced clinical stage and poor disease prognosis, as a rule. Contrary to mentioned above, the FOS gene was involved in growth inhibition of carcinoma cells [25], due to triggered apoptosis [26]. Moreover, FOS expression was lower in cancer associated prostate fibroblasts, compared with hyperplastic ones [27]. According to our results, the possible FOS activation in CNT could be due to the tumor impact on surrounding tissues; alternatively, it is due to the mixture of normal and cancer cells in CNT. Increased RE of EFNA5 was observed more frequently in carcinomas (17 out of 37), compared with adenomas (3 out of 16). Similar results were observed in CNT (18 out of 29), compared with adenomas (3 out of 16). This gene encodes ephrin-A5. It is a member of the ephrin gene family, which plays role in cell adhesion [28]. It was shown that EFNA5 was decreased in chondrosarcomas [29] and gliomas, compared with normal tissues. It acts as a tumor suppressor in gliomas, regulating negatively the epidermal growth factor receptor [30]. Hence, the increased RE of EFNA5 in carcinomas points out the possible activation of EFNA5 associated signaling pathway, leading to subsequent aberrations in cell adhesion in adenomas and carcinomas.

The increased RE levels of the IL1B gene were more frequently detected in CNT (17 out of 29) compared with adenomas (4 out of 16). It may be due to general inflammation in prostate gland that is often associated with carcinogenesis. The similar tendency (but not significant) was found in carcinomas ( 14 samples from 37) compared with adenomas ( 4 samples from 16) that supports our hypothesis. Our data suggest that the higher PSA levels (but no more than $20.0 \mathrm{ng} / \mathrm{ml}$ ) correlated with increased RE of the IL $1 B$ gene. According to our results, the prostate cancer patients showing increased IL1B RE levels may be at the intermediate risk for biochemical recurrence, as described in the guidelines of the European Association of Urology.

At the other hand, IL1B encodes one of the proinflammatory interleukins that is usually elevated in prostatic secretions of the patients with the chronic prostatitis [31]. It may be a valuable marker of inflammation in be- nign prostate hyperplasia [32]. Thus, further investigations on a larger group of adenomas should be performed. Our results support an idea that the NF-KB signaling pathway is activated in both, carcinomas and in CNT, because IL $1 B$ is one of activators of the NF-KB pathway [33].

RElevels of TGFB1 were diminished in adenomas more frequent ( 6 out of 16 ) than in CNT ( 1 out of 29 ). Also, REalterations (both, increase and decrease) was found more frequently in carcinomas (13 out of 37) compared with CNT (2 out of 29). This gene encodes the transforming growth factor beta 1, regulating cell differentiation, proliferation, migration, and apoptosis [34]. It plays the opposite roles in different types of prostate tumors: it acts as a growth inhibitor in normal tissues and early stage tumors [35] and as a promoter in advanced prostate cancers [36]. The opposite direction of alterations in RE levels of TGFB 1 in carcinomas compared with CNT could be due to variations of individuals, reflecting different stages of disease. The similar changes in RE of the FOS, EFNA5, and IL1B genes in carcinomas and CNT could be due to heterogeneity of both, cancers and CNT, i.e. cancer tissue may contain some proportion of normal cells, and vice versa._Noteworthy, RE of the PLAU gene were frequently decreased in carcinomas, compared with the paired CNT samples. This should be validated on the larger groups of patients as well. No correlation was found between REand Gl and/ or PSA level. No significant differences of REalteration frequencies was detected in carcinomas with $\mathrm{Gl} \leqslant 7$ and $>7$, in contrast with comparison of adenomas and carcinomas with $\mathrm{Gl} \leqslant 7$ for FOS and EFNA5 genes. RE of the FOS gene were frequently increased in carcinomas with $\mathrm{Gl} \leqslant 7 \mathrm{com}$ pared with adenomas. RE of the EFNA5 gene were altered in the majority of cases (both, decreased and increased) in the same comparison groups. The investigation of the possible molecular mechanisms of the involvement of the FOS and EFNA5 in prostate cancer pathogenesis requires the further experimental work. A nonparametric regression analysis has shown the significant correlation of the increased RE level of IL1B in carcinomas compared with CNT and the PSA level that may be used as an additional risk factor for the patients with intermediate risk of biochemical recurrence. However, this should be validated on the larger patient groups.

Summarizing, results of the present work correspond to the earlier findings, obtained with cell lines [8,9]. Currently, we found the significant changes in RE for 5 out of 7 genes, comparing malignant and non-malignant prostate tissues, namely for EFNA5, FOS, IL1B, PLAU, and TGFB1. Thus, the PLAU gene is expressed the lower levels in carcinomas, compared with the paired CNT, which is in agreement with our data on $\mathrm{LNCaP}$ and DU145, compared with PNT2 cells.

\section{CONCLUSION}

In the present work we have found the significant alterations in the RE levels of the FOS, EFNA5, IL1B, and TGFB1 genes in prostate tumors, comparing to CNT. We have found that FOS and EFNA5 were more frequently overexpressed in carcinomas with $\mathrm{Gl} \leqslant 7$, compared with adenomas. On contrary, PLAU expres- 
sion levels were decreased more frequently in prostate cancers, compared with CNT. Noteworthy, we found positive correlation between IL1B expression level and PSA for patients with slight PSA increase. The EFNA5, FOS, IL1B, PLAU, and TGFB1 genes that showed significant expression alterations in prostate tumors, compared with CNT, may play role in prostate cancer development and should be further investigated.

\section{REFERENCES}

1. Ferlay J, Soerjomataram I, Dikshit R, et al. Cancer incidence and mortality worldwide: sources, methods and major patterns in GLOBOCAN 2012. Int J Cancer 2015; 136: E359-86.

2. Fedorenko ZP, Michailovich YY, Goulak LO, et al. Cancer in Ukraine, 2014-2015. Ukrainian cancer registry statistics, 2016. Bulletin of National Cancer Registry of Ukraine, 17: 5.

3. Boutros PC, Fraser M, Harding NJ, et al. Spatial genomic heterogeneity within localized, multifocal prostate cancer. Nat Genet 2015; 47: 736-45.

4. Villers A, McNeal JE, Freiha FS, Stamey TA. Multiple cancers in the prostate. Morphologic features of clinically recognized versus incidental tumors. Cancer 1992; 70: 2313-8.

5. Ibeawuchi C, Schmidt H, Voss R, et al. Genome-wide investigation of multifocal and unifocal prostate cancer - are they genetically different? Int J Mol Sci 2013; 14: 11816-29.

6. D'Amico AV, Moul J, Carroll PR, et al. Cancer-specific mortality after surgery or radiation for patients with clinically localized prostate cancer managed during the prostate-specific antigen era. J Clin Oncol 2003; 21: 2163-72.

7. Nichol AM, Warde P, Bristow RG. Optimal treatment of intermediate-risk prostate carcinoma with radiotherapy: clinical and translational issues. Cancer 2005; 104: 891-905.

8. Rosenberg EE, Prudnikova TY, Gerashchenko GV, et al. Search for genes - potential markers of aggressiveness and metastasis for human prostate cancer. Biopolym Cell 2013; 29: 499-505 (in Ukrainian).

9. Rosenberg EE, Gerashchenko GV, Kashuba VI. Comparative analysis of gene expression in normal and cancer human prostate cell lines. Ukr Biochem J 2014; 86: 119-28 (in Ukrainian).

10. Le Bras GF, Taubenslag KJ, Andl CD. The regulation of cell-cell adhesion during epithelial-mesenchymal transition, motility and tumor progression. Cell Adh Migr 2012; 6: 365-73.

11. Zhang ZW, Yang ZM, Zheng YC, Chen ZD. Transgelin induces apoptosis of human prostate LNCaP cells through its interaction with p53. Asian J Androl 2010; 12: 186-95.

12. Malinin NL, Boldin MP, Kovalenko AV, Wallach D. MAP3K-related kinase involved in NF-kappaB induction by TNF, CD95 and IL-1. Nature 1997; 385: 540-4.

13. Banyard J, Chung I, Migliozzi M, et al. Identification of genes regulating migration and invasion using a new model of metastatic prostate cancer. BMC Cancer 2014; 14: 387.

14. Han G, Lu SL, Li AG, et al. Distinct mechanisms of TGF-beta1-mediated epithelial-to-mesenchymal transition and metastasis during skin carcinogenesis. J Clin Invest 2005; 115: 1714-23.

15. Uluçkan Ö, Guinea-Viniegra J, Jimenez M, Wagner EF. Signalling in inflammatory skin disease by AP-1 (Fos/ Jun). Clin Exp Rheumatol 2015; 33 (4 Suppl 92): S44-9.

16. Schmidt U, Fuessel S, Koch R, et al. Quantitative multigene expression profiling of primary prostate cancer. Prostate 2006; 66: 1521-34.

17. Kochetov AG, Liang OV, Masenko VP, et al. Methods of statistical processing of medical data: Methodological re- commendations for residents and graduate students of medical schools, researchers. Moscow: RCRMC, 2012. 12 p. (in Russian).

18. Resnick MJ, Koyama T, Fan KH, et al. Long-term functional outcomes after treatment for localized prostate cancer. N Engl J Med 2013; 368: 436-45.

19. Wyatt AW, Mo F, Wang Y, Collins CC. The diverse heterogeneity of molecular alterations in prostate cancer identified through next-generation sequencing. Asian J Androl 2013; 15: 301-8.

20. Ikromov O, Alkamal I, Magheli A, et al. Functional epigenetic analysis of prostate carcinoma: a role for SeryltRNA synthetase? J Biomark 2014; 2014: 362164.

21. Cunha GR, Hayward SW, Dahiya R, Foster BA. Smooth muscle-epithelial interactions in normal and neoplastic prostatic development. Acta Anat (Basel) 1996; 155: $63-72$.

22. Durchdewald M, Angel P, Hess J. The transcription factor Fos: a Janus-type regulator in health and disease. Histol Histopathol 2009; 24: 1451-61.

23. Kang KW, Lee MJ, Song JA, et al. Overexpression of goosecoid homeobox is associated with chemoresistance and poor prognosis in ovarian carcinoma. Oncol Rep 2014; 32: 189-98.

24. Gamberi G, Benassi MS, Bohling T, et al. C-myc and c-fos in human osteosarcoma: prognostic value of mRNA and protein expression. Oncology 1998; 55: 556-63.

25. Zhang T, Fan X, Song L, et al. c-Fos is involved in inhibition of human bladder carcinoma T24 cells by brazilin. IUBMB Life 2015; 67: 175-81.

26. Du L, Wu W. A mimic of phosphorylated prolactin induces apoptosis by activating AP-1 and upregulating p21/ waf1 in human prostate cancer PC3 cells. Oncol Lett 2012; 4: $1064-8$.

27. Reinertsen T, Halgunset J, Viset T, et al. Gene expressional changes in prostate fibroblasts from cancerous tissue. APMIS 2012; 120: 558-71.

28. Zhou R. The Eph family receptors and ligands. Pharmacol Ther 1998; 77: 151-81.

29. Kalinski T, Röpke A, Sel S, et al. Down-regulation of ephrin-A5, a gene product of normal cartilage, in chondrosarcoma. Hum Pathol 2009; 40: 1679-85.

30. Li JJ, Liu DP, Liu GT, Xie D. EphrinA5 acts as a tumor suppressor in glioma by negative regulation of epidermal growth factor receptor. Oncogene 2009; 28: 1759-68.

31. Nadler RB, Koch AE, Calhoun EA, et al. IL-1ß and TNF- $\alpha$ in prostatic secretions are indicators in the evaluation of men with chronic prostatitis. J Urol 2000; 164: 214-8.

32. Vela Navarrete R, Garcia Cardoso JV, Barat A, et al. BPH and inflammation: pharmacological effects of Permixon on histological and molecular inflammatory markers. Results of a double blind pilot clinical assay. Eur Urol 2003; 44: 549-55.

33. Haseeb A, Chen D, Haqqi TM. Delphinidin inhibits IL- $1 \beta$-induced activation of NF- $\chi$ B by modulating the phosphorylation of IRAK-1(Ser376) in human articular chondrocytes. Rheumatology (Oxford) 2013; 52: 998-1008.

34. Massagué J. TGF $\beta$ signalling in context. Nat Rev Mol Cell Biol 2012; 13: 616-30.

35. Guo Y, Kyprianou N. Overexpression of transforming growth factor (TGF) betal type II receptor restores TGFbeta1 sensitivity and signaling in human prostate cancer cells. Cell Growth Differ 1998; 9: 185-93.

36. Zhang Q, Chen L, Helfand BT, et al. TGF- $\beta$ regulates DNA methyltransferase expression in prostate cancer, correlates with aggressive capabilities, and predicts disease recurrence. PLoS One 2011; 6: e25168. 